\title{
A Research on Dynamic System of Innovation and Development of Commerce Industry in Tongzhou District of Beijing
}

\author{
Shuai Liu \\ School of Business, Beijing Wuzi University, Beijing, China \\ Email: 18813053923@163.com
}

How to cite this paper: Liu, S. (2016) A Research on Dynamic System of Innovation and Development of Commerce Industry in Tongzhou District of Beijing. American Journal of Industrial and Business Management, 6, 1066-1074

http://dx.doi.org/10.4236/ajibm.2016.611100

Received: October 22, 2016

Accepted: November 19, 2016

Published: November 22, 2016

Copyright $\odot 2016$ by author and Scientific Research Publishing Inc. This work is licensed under the Creative Commons Attribution International License (CC BY 4.0).

http://creativecommons.org/licenses/by/4.0/

\begin{abstract}
Commerce industry has the function of industry leader as a link between producers and consumers. In recent years, Tongzhou District, as the city's vice center of Beijing City, has developed rapidly. However, there are still a lot of problems in the development of Tongzhou District's commerce industry, and the research of the dynamic system for its innovative development plays an important role in solving these problems. This paper analyzes dynamic system of commerce industry's innovation and development. All the researches which have done in this paper are meant to provide method to analyze dynamic system of commerce industry and make it better.
\end{abstract}

\section{Keywords}

Commerce Industry, Dynamic System, Innovation and Development

\section{Introduction}

2015 China's gross domestic product (GDP) was 67 trillion and 670 billion yuan, an increase of $6.9 \%$. Compared to 2014's 7.4\% growth slowed further, China economy is entering a new economic norm. But with the deepening of the new economic norm and the implementation of the reform of the supply side, China's consumer confidence will gradually increase; the consumer demand will be further expanded. Commerce industry has the function of industry leader as a link between producers and consumers. Commerce industry is an important aspect of reflecting the economic development and social features of a region, but also to expand domestic demand. The future of China's trade industry still has a larger development space. In recent years, Tongzhou District, as the city's vice center of Beijing City, has developed rapidly. Retail sales of social con- 
sumer goods in Tongzhou District from 2005 to 2015 are shown in Figure 1. However, there are still a lot of problems in the development of Tongzhou District's commerce industry, and the research of the dynamic system for its innovative development plays an important role in solving these problems [1].

\section{Questions in the Development of Tongzhou District's Commerce Industry}

\subsection{Starting Lately of Commercial Facilities}

As Tongzhou District's trade and business facilities started late, the business environment is not very mature. At present, Tongzhou District business matching mainly to meet the basic needs of the daily life of the residents, although there are tens of thousands of outlets, but the actual grade, the larger the number of shopping centers is not much. 2006, the retail giant Carrefour in China's first suburban store was officially settled in Tongzhou [2]. This situation led to the size of the housing market in Tongzhou and the size of the business sector is not proportional to the size of the main consumer groups cannot find a suitable place for the consumer.

\subsection{Lack of Agglomeration Effect and Regional Radiation Force}

Tongzhou has a strong cultural heritage, but in the late development process, has been relatively slow. Tongzhou has not yet formed as the Yangtze River Delta, Pearl River Delta region as the intensive business. Tongzhou District commerce enterprises are mostly small and lack of competitiveness. Regional industrial layout is relatively dispersed, it is difficult to play a gathering effect; gathering area is less in quantity, the agglomeration agglomeration absorb ability is weak.

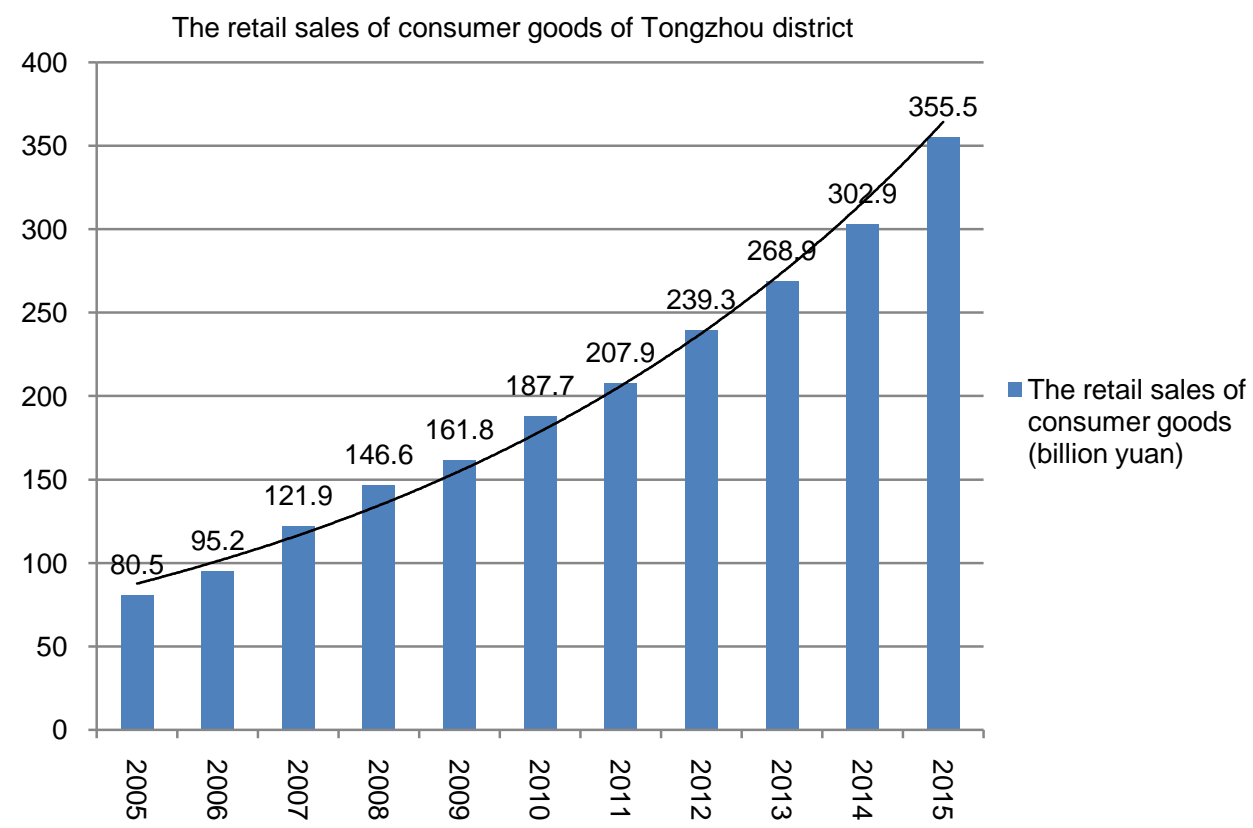

Figure 1. The retail sales of consumer goods of Tongzhou district from 2005 to 2105. 


\subsection{Not High in Commodity Brand Level}

Tongzhou currently lacks the world's well-known commercial enterprises and commercial brands. And it is the lack of international commercial brand flagship store, the concept store, the domestic commercial brand stores, brand hierarchy has yet to be improved. At present, Tongzhou District's commercial brands can not fully reflect the heavy history and cultural characteristics of Tongzhou, but also the lack of a unique commercial landscape, commercial culture and business image. In short, the characteristics of Tongzhou District's business needs to be further developed [3].

\subsection{Low Chain Degree in the Wholesale and Retail Industry}

The wholesale and retail trade is an important part of the trade and industry. Tongzhou District in various districts and counties in Beijing development is relatively backward. Not only the capital function core area and the city function development area are far apart, but also does not have the competitive advantage compared with other city development new area.

\section{The Establishment of Dynamic System Model}

This paper establishes dynamic system models for commerce industry' innovation and development, which includes the automatic force subsystem, the environment force subsystem and the cultural force subsystem. Among them, the automatic force subsystem includes four aspects: economic interests target and its driven force, subjective innovation value and its influential force, innovation incentive mechanism and its catalytic force, necessary for Long-term development and its durable force. The environment force subsystem includes four aspects: market demand and its pulling force, market competition and its stress force, market resources and its constrained force, governmental measures and its guiding force. The cultural force subsystem includes two aspects: corporate culture and its appeal force, social culture and its pushing force.

The factors of dynamic system models are interactional and interdependent. These factors are mutually inhibited when their forces have opposite direction. And when their forces have same direction, these factors are mutually reinforcing relationship. Besides, the different subsystems also affect each other. Therefore, the open circumferential dynamic model of commerce industry' innovation and development is just as Figure 2 shown.

\section{Analysis of Operation Mechanism of Dynamic System}

\subsection{The Dynamic Factors and the Roles of the Dynamic System}

\subsubsection{The Automatic Force Subsystem}

1) Economic interest target is the pursuit of excess profits in the commerce industry. The survival motivation of commerce industry is the driving force of economic benefits maximization. In order to achieve the goal of maximizing economic benefits, the enterprises can take the innovation and development as the core competence [4]. The 


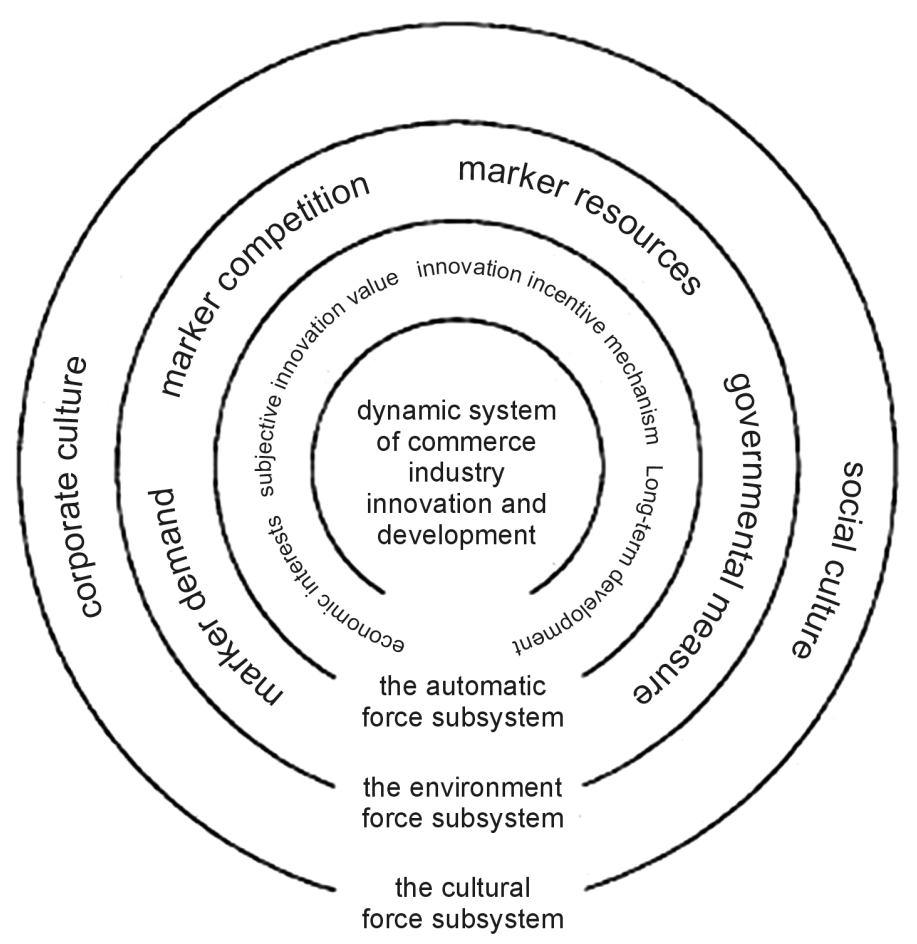

Figure 2. Open circumferential dynamic model.

function of economic interest target is driving the commerce industry innovation and development.

2) The value of subjective innovation refers to the innovation consciousness, innovation demand and leaders' sense of crisis. We need to be clear that the leaders are the core strength of enterprises' innovation and development. If the leaders hold a strong sense of innovation, they can lead the whole enterprise to innovate and change.

3) Innovation incentive mechanism is a number of measures which can encourage various forms of innovation form policy makers, technical staff, managers and ordinary employees [5]. The reasonable innovation incentive mechanism can stimulate the innovation enthusiasm and the desire of the related personnel. The function of this factor is producing and reinforcing the commerce industry innovation and development.

4) The need for long term development can realize the enduring and healthy development of enterprises. It makes the enterprises be in a dominant position among market competition. In an increasingly competitive environment, long-term development is the lasting goal of the enterprise. This factor is able to maintain the sustainable development of innovation and development of commerce industry.

\subsubsection{The Environment Force Subsystem}

1) Market demand is the basic starting point for the innovation and development of business enterprises, including consumer demand for products, services and demand for the development of business enterprises. Meeting the market demand not only provide commerce industry with the opportunity to get a profit, but also bring the market competition [6]. Commerce industry obtain competitive advantage through innovation 
and development, and it will better satisfy the market demand, get more profit and promote well cycle development. The function of this factor is pulling and stimulating the commerce industry' innovation and development.

2) Market competition is the response measures taken by commerce industry in the face of peer competition. If companies want to ensure that they are not eliminated in the competition, it is necessary to enhance their competitive strength by various means. Market competition is the pressure on the innovation and development of the business enterprise.

3) Market resource includes human resources, material resources, information resources, assets and natural resources in the process of commerce industry' innovation and development. If some conditions are not satisfied, it will inevitably lead to the bottleneck and restriction of commerce industry.

4) Government measures are the policy and legal system that the government needs to make to develop the innovation and development of enterprises in different levels of society according to the needs of national economic development. Commerce industry can be based on government measures to develop and innovate in a directive and purposive way. Government measures are regarded to be the guiding force for the development and innovation of commerce industry [7].

\subsubsection{The Cultural Force Subsystem}

1) Enterprise culture is the sum of the value idea, the team consciousness, the behavior way and the thought pattern of the enterprise. Enterprise culture exerts a subtle influence on the enterprise's decision-making, operation and innovation. The corporate culture of encouraging innovation and tolerating failure plays an important role in the innovation and development of commerce industry. Enterprise culture is an infectious force in the process of innovation and development of commerce industry.

2) The social culture is the influence of the innovation culture on the enterprises innovation development in the macro social environment of the enterprises. Encouraging innovative social culture can promote the development of commerce industry, so commerce enterprise does not fear failure in the face of innovation risk. The role of social culture is to promote innovation and development of commerce industry.

\subsection{Analysis of Interaction among the Dynamical Systems}

\subsubsection{Analysis of Interaction among Factors in the Automatic Force Subsystem}

Economic interest target can generate the driving force for commerce industry' innovation and development. It will make commerce industry improve labor productivity to obtain excess profits and achieve long-term development. Subjective innovation value will exert a subtle influence on economic benefits and long-term development of commerce industry [8]. The subjective innovation value of encouraging innovation can make enterprises overcome difficulties, improve profit and realize long-term development. Innovation incentive mechanisms have a direct catalytic effect for innovation and development. The reasonable degree of innovation incentive mechanisms has a close interaction with the realization of economic benefits, the formation of subjective inno- 
vation value and the long-term development of enterprises.

\subsubsection{Analysis of Interaction among Factors in the Environment Force Subsystem}

Lower market demands and shortage of resources will lead to increase market competition among commerce industry. Huge competitive pressure will promote commerce industry putting more focus on scientific research and innovation. Only in this way can commerce industry enhance their core competitiveness and realize their innovation and development [9]. The government's policy just likes one pair of visible hands which can carry out macroeconomic regulation on market demand, market resources and competition. And it will guide the innovation and development of commerce industry actively.

\subsubsection{Analysis of Interaction among Factors in the Cultural Force Subsystem} The culture of enterprises is the sum total of some stable cultural concept, code of conduct and standard of morality which are formed in the development of enterprises and united in the same direction of enterprises. The culture of commerce industry has a strong influence on the value pursuit, innovation direction and the way of realization.

Enterprises' culture will be influenced by social culture. If social culture is inspiring and tolerant, commerce industry will establish their culture that enterprises encourage employees to innovate and inclusive their failures [10]. On the contrary, when most of enterprises are constantly innovating, they will form a trend of social and cultural innovation.

\subsubsection{Analysis of Interaction among Subsystems}

The relationship among three subsystems of dynamical systems is mutual influence. The market conditions and policies factors of environmental subsystem directly affect the economic benefits, subjective innovation value, innovation incentive mechanism and long-term development of automatic force system [11]. On the other hand, the changes in the system of automatic force subsystem can promote the formation of the environmental subsystem. Culture subsystem and environment subsystem are interaction effect. The changes of social culture and enterprise culture are affected by the factors of environment subsystem. Social culture and enterprise culture of culture subsystem is the value orientation of automatic force subsystem. On the contrary, the adjustment of automatic force subsystem will have indirect influence on social culture and enterprise culture.

In summary, interaction among dynamical systems as shown in Figure 3.

\section{Suggestions}

\subsection{Accelerations the Transformation of Government Functions}

By the government of Tongzhou District to set up a special fund for the development and construction of trade and industry, and served as incubator role. Through the development of relevant policies to encourage and support, in line with industry oriented 


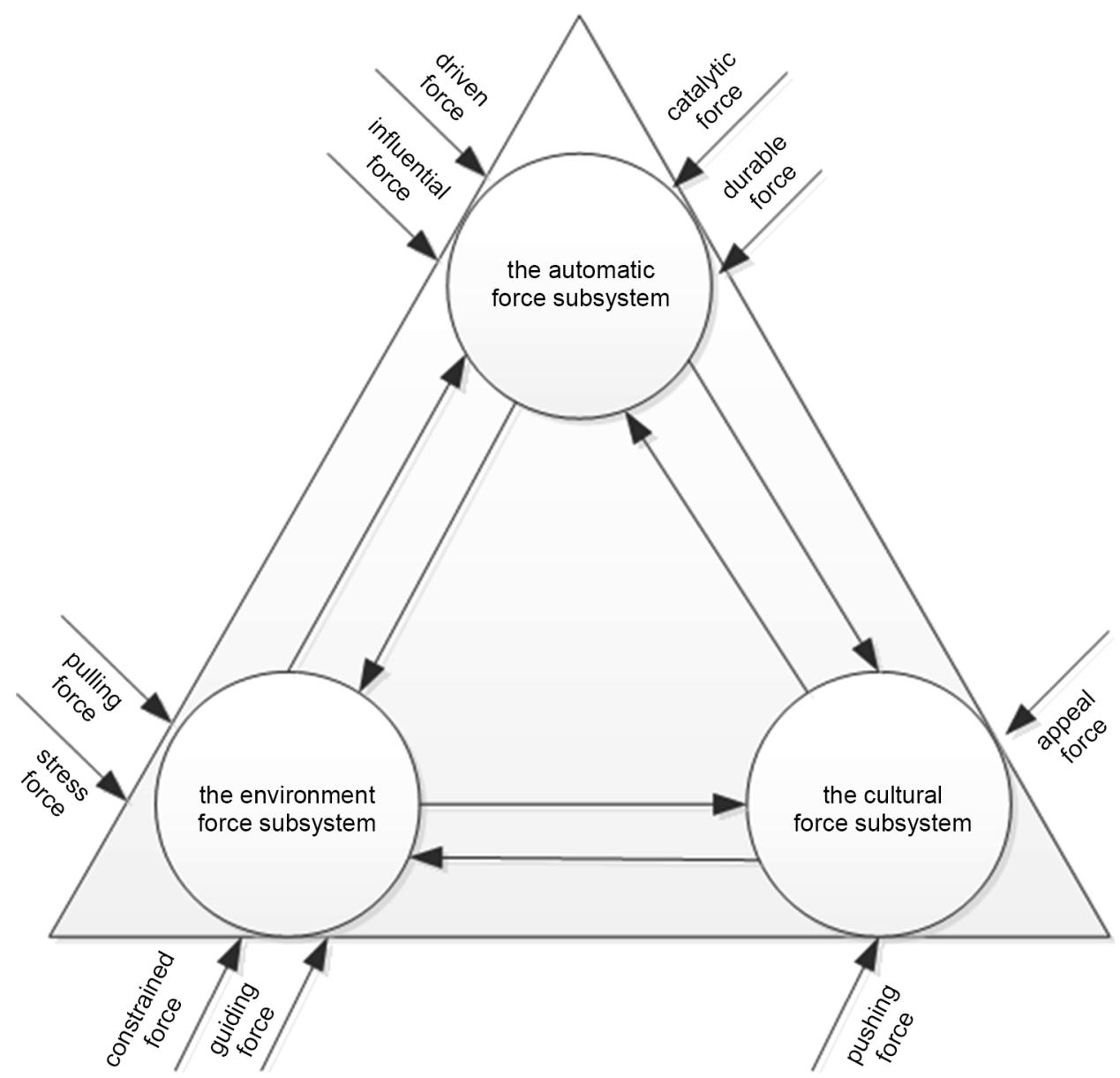

Figure 3. Interaction among dynamical systems.

enterprises to provide funds, management and other facilities, and to build a platform for business enterprises. Do not meet the high-end business platform positioning industry, regional logistics base and regional professional market, such as the eight mile bridge to market through administrative means to move out of Tongzhou, and vigorously expand the matching high-end business platform in the industry area, such as the Songzhuang cultural experience area, Zhang Jia Wan Yun town tourism district. At the same time improve the supporting roads, communications, utilities and other infrastructure, improve the overall quality of science and education and other public service facilities, promote market-oriented reform of municipal infrastructure, the implementation of the functions of innovation, promote the separation between government and enterprises, carry out their duties, give full play to their role.

\subsection{The Formation of High-End Business Cluster}

Industry enterprises as the main body of the innovation and development of Tongzhou District's trade and industry is determined by its internal drive power system elements. Tongzhou District business enterprises to change to the Grande Canale as the axis, the small shops along the street scattered layout of the "point axis" pattern, and to bring 
together many of the district level business center constitute the "multi polar dispersion" of the development of the network pattern. Finally, entrepreneurs have to be bold to try. For example, changing the traditional business sector is responsible for sales function, and to experience life experience center center, the direction of development, and relying on the resource advantage of shopping malls, supermarkets, shopping malls and other line to carry out $\mathrm{O} 2 \mathrm{O}$ sales. At the same time to develop high-end catering industry, exhibition industry, entertainment industry, the formation of high-end business industry gathering area.

\subsection{Integratation into the Coordinated Development Actively}

We cannot unilaterally consider the problem. We cannot have a one-sided view of commerce industry. Tongzhou District government should seize the opportunity to develop the integration of Beijing-Tianjin-Hebei, so as to define their own position and play their own advantages. In order to avoid unnecessary competition, Tongzhou District commerce industry realizes the development better. Meanwhile, Tongzhou District government should improve the level of environmental management and build a better place for the harmonious development of ecology and economy.

\section{Acknowledgements}

This paper is supported by the Funding Project for Research on the innovation and development of Tongzhou District trade and Industry under the International Trade Center (ID: PXM2014-014214-000073). The author would like to deeply thank this project for the generous support.

\section{References}

[1] Hossain, M. (2015) A Review of Literature on Open Innovation in Small and Medium-Sized Enterprises. Journal of Global Entrepreneurship Research, 1, 34-50. https:/doi.org/10.1186/s40497-015-0022-y

[2] Halme, M. and Korpela, M. (2014) Responsible Innovation toward Sustainable Development in Small and Medium-Sized Enterprises: A Resource Perspective. Business Strategy and the Environment, 8, 547-566. https:/doi.org/10.1002/bse.1801

[3] Shao, M. (2013) Research on Business Model Innovation of the Commerce Industry Integrated with QFD and TRIZ. Yangzhou University.

[4] Wei, G.C. (2015) Study on the Innovation of Fresh Products Logistics Model in Chinese Commerce Industry. China Business and Market, 5, 43-50.

[5] Zhang, Y.M., Zhang, B.S. and Zhang, X.Y. (2014) Marketing Strategy Innovation of Commerce Enterprise Market Development. China Journal of Commerce, 25, 29-30.

[6] Alyoubi, A.A. (2015) Commerce in Developing Countries and How to Develop Them during. Procedia Computer Science, 10, 479-483. https:/doi.org/10.1016/j.procs.2015.09.127

[7] Morteza, G., Hong, T.S. and Craig, S. (2013) B2B Commerce Success among Small and Medium-Sized Enterprises: A Business Network Perspective. Journal of Organizational \& End User Computing, 27, 23-32.

[8] Baghdadi, Y. (2016) A Framework for Social Commerce Design. Information Systems, 8, 95-113. https:/doi.org/10.1016/j.is.2016.03.007 
[9] Grochal-Brejdak, M. (2016) Methodology of Research on Internationalisation Process of Commerce Industry. Management, 16, 51-66.

[10] Park, S. (2014) Analyzing the Efficiency of Small and Medium-Sized Enterprises of a National Technology Innovation Research and Development Program. Springer Plus, 3, 403. https:/doi.org/10.1186/2193-1801-3-403

[11] Duplenko, N. (2013) The Development of a Mechanism for Stimulating the Innovative Activity of Small Enterprises. Vestnik Immanuel Kant Baltic Federal University, 3, 107-113.

Submit or recommend next manuscript to SCIRP and we will provide best service for you:

Accepting pre-submission inquiries through Email, Facebook, LinkedIn, Twitter, etc.

A wide selection of journals (inclusive of 9 subjects, more than 200 journals)

Providing 24-hour high-quality service

User-friendly online submission system

Fair and swift peer-review system

Efficient typesetting and proofreading procedure

Display of the result of downloads and visits, as well as the number of cited articles

Maximum dissemination of your research work

Submit your manuscript at: http://papersubmission.scirp.org/

Or contact ajibm@scirp.org 